\title{
Genetic Analysis of Tertiary Rice Panicle Branches
}

\author{
Tri Hastini ${ }^{1}$, Willy Bayuardi Suwarno ${ }^{2}$, Munif Ghulamahdi ${ }^{2}$, and Hajrial Aswidinnoor ${ }^{2, *}$ \\ ${ }^{1}$ West Java Assessment Institute for Agricultural Technology, Indonesian Agency for Agricultural \\ Research and Development, Ministry of Agriculture, Jl. Kayuambon No. 80 Lembang Bandung Barat \\ 40391 West Java, Indonesia \\ ${ }^{2}$ Department of Agronomy and Horticulture, Faculty of Agriculture, IPB University, Jl. Meranti \\ Darmaga , Bogor 16630, Indonesia
}

\begin{abstract}
Panicle branching trait of rice is one of the key factors in detemining grain yield. This study was aimed to elucidate the genetic inheritance pattern of the tertiary rice panicle branches trait. Six rice populations i.e $\mathrm{F}_{1}, \mathrm{~F}_{1} \mathrm{R}, \mathrm{F}_{2}, \mathrm{~F}_{2} \mathrm{R}, \mathrm{BC}_{1} \mathrm{P}_{1}$, and $\mathrm{BC}_{1} \mathrm{P}_{2}$ generation including parental lines were generated as materials. The experiment was conducted at IPB University, Bogor, Indonesia from April 2017 to February 2019. Several parameters of genetic inheritance was observed. The result revealed that the inheritance of the tertiary panicle branching was controlled by many genes with the high broad-sense heritability and the moderate narrow-sense ones. Based on the scaling test, it was observed that additive dominant model did not fit to the number of tertiary branches and the number of grains of tertiary panicle branches. These phenomenons suspected may due probably to the effect of epistasis. In the advanced analysis employed by using the joint scaling test revealed that the gene action of the number of tertiary branches and number of grains on the tertiary branches were additive and additive $\times$ additive.
\end{abstract}

\section{Introduction}

The economic and related-traits generally included into quantitative traits. Rice panicle branching is one of the traits that related to rice economic trait. Rice yield is determined by panicle size and structure [1]. A large number of rice spikelet increased because of accommodation of extra those by secondary branches like in New Plant Type (NPT) rice [2]. In the last few recent years many researchers has conducted study in rice panicle branching and the mechanism of its formation [3].

Rice researchers has carried out the experiment related to panicle branching. Mohapatra studied about how to effort breeding program by changing plant type in favour of extra heavy-panicles through physiological approach [2]. This study has been initiated as early as 1987. Long before this study, there had been a report that the inheritance of panicle types of rice grouped by the nodal distribution pattern of the number of spikelet on the secondary panicle branches. The result of those study indicated that the genetical factor was controlling the number of spikelet per primary panicle branch. It was also reported that the $S u-1, S u-2$ and Act genes was predicted as regulatory genes. These genes were predicted to

\footnotetext{
${ }^{*}$ Corresponding author: hajrial@apps.ipb.ac.id
} 
be stimulated by $S s p$ genes, and controlled the structural genes. Eventually, initiation and growth of the spikelets on the lower secondary branches were expressed. Recently, Yang et al. [4] studied panicle related genes through biochemical analysis, and it was revealed that there were complex regulations. MiR156 as transcriptional regulation influenced many panicle related genes.

The primary branches, secondary branches, and tertiary branches of panicle traits of $\mathrm{F}_{2}$ and $F_{2} R$ population analysed by skewness and kurtosis [5]. The results showed that the third of panicle branching traits had the broad-sense heritability of $0.91-0.97$ in $F_{2}$ population, and $0.86-0.87$ in $\mathrm{F}_{2} \mathrm{R}$ population. All these traits were controlled by multiple genes. Primary panicle branches was controlled by additive gene, the same case also reported by Ramadhan [6]. Meanwhile secondary and tertiary panicle branches were controlled by additive and complementary epistatic genes.

References that was explaining about tertiary panicle branches and its inheritance pattern was still rare. How the tertiary panicle branches inherited was still not explained. How the effect of maternal, the broad-sense heritability and narrow-sense heritability of tertiary panicle branches were still not known well. Inheritance pattern method will elucidate the genetical and environment variance more thoroughly. The present research was undertaken to understand the inheritance pattern of tertiary rice panicle branches involving contrasting parents in panicle branching traits.

\section{Materials and methods}

The experiment was conducted at IPB research station, Dramaga Bogor, Indonesia from April 2017 until February 2019. Genetic material used in this experiment were IPB158-F-5 as the first parent (denote as $\mathrm{P}_{1}$ ) and IPB180-F-12 as the second parent (denote as $\mathrm{P}_{2}$ ). The parents were distinct panicle characteristics as shown in Table 1.

Table 1. Panicle characteristics of parents selected for crossing

\begin{tabular}{|l|l|}
\hline \multicolumn{1}{|c|}{ Parents } & \multicolumn{1}{c|}{ Panicle characteristics } \\
\hline IPB158-F-5 & many tertiary branches, short panicle, \\
\hline IPB180-F-12 & few/absent tertiary branches, long panicle, included as heavy panicle \\
\hline
\end{tabular}

As parents, $\mathrm{P}_{1}$ and $\mathrm{P}_{2}$ were planted in plastic pot, each were 20 plants. The $\mathrm{F}_{1}$ generation was formed by crossing of $\mathrm{P}_{1} / \mathrm{P}_{2}$, while $\mathrm{F}_{1} \mathrm{R}$ generation was obtained reciprocally. The $\mathrm{F}_{1}$ population was planted in plastic pot to obtain $F_{2}$ seed, and $F_{2} R$ was derived from $F_{1} R$. $\mathrm{BC}_{1} \mathrm{P}_{1}$ was obtained from crossing of $\mathrm{F}_{1} / \mathrm{P}_{1}$, and $\mathrm{BC}_{1} \mathrm{P}_{2}$ was from $\mathrm{F}_{1} / \mathrm{P}_{2}$. The populations used as treatment in the inheritance pattern experiment were $\mathrm{P}_{1}, \mathrm{P}_{2}, \mathrm{~F}_{1}, \mathrm{~F}_{1} \mathrm{R}, \mathrm{F}_{2}, \mathrm{~F}_{2} \mathrm{R}, \mathrm{BC}_{1} \mathrm{P}_{1}$, and $\mathrm{BC}_{1} \mathrm{P}_{2}$ in the third season. The third season experiment was conducted at controlled rice field.

The traits observed were number of tertiary branches per panicle (NTB), number of grain on tertiary branches per panicle (NGT), and tertiary branches grain number percentage $(\% \mathrm{NGT})$. The observation was done to whole individual plants of all populations, and each was observed three panicles (according to the previous study, three panicles per plant was enough to be a sample in the homogenous population). While in the heterogenous population $\left(\mathrm{F}_{2}\right.$ and $\left.\mathrm{F}_{2} \mathrm{R}\right)$ were observed four panicles per plant.

Data was analyzed by using STAR and PBTools softwares from IRRI (open source). Number of controlling gene was estimated by using STAR to analyse skewness and kurtosis of $F_{2}$ and $F_{2} R$ population. The equation of skewness and kurtosis according to Roy method as presented by Herawati et.al. [7] as follows:

$$
\text { Skewness }=\frac{\sum_{i=1}^{N}(Y i-\bar{Y})^{3}}{(N-1) S^{3}}
$$




$$
\text { Kurtosis }=\frac{\sum_{i=1}^{N}(Y i-\bar{Y})^{4}}{(N-1) S^{4}}
$$

where,

$\mathrm{Yi}=\mathrm{i}$-th genotype value,

$\bar{Y}=$ means genotype,

$\mathrm{S}=$ standard deviation

$\mathrm{N}=$ number of observation.

Advanced analysis for skewness and kurtosis value were counted through $\mathrm{Z}$ test statistic.

$$
\begin{aligned}
& Z s=\frac{S}{S E_{S}} \\
& Z_{K}=\frac{K}{S E_{K}}
\end{aligned}
$$

where,

$\mathrm{S}=$ skewness,

$\mathrm{K}=$ kurtosis,

$\mathrm{SE}_{\mathrm{S}}=$ standard error of skewness,

$\mathrm{SE}_{\mathrm{K}}=$ standard error of kurtosis, according to two ways critical test for ZS and ZK were $\mathrm{Z} 0.05 / 2=1.96$ and $\mathrm{Z} 0.01 / 2=2.75$.

The significant of skewness is based on $\mathrm{Z}$ value, H0 is accepted (non-significant) if $1.96 \leq Z \leq 1.96$ and $-2.75 \leq Z \leq 2.75$ at significant level of $\alpha 0.05$ and 0.01 respectively. Skewness value indicates epistatic effect, while kurtosis value indicates the number of gene which has a role in controlling a trait. Epistatic effect will be absent if skewness value $=0$, skewness $>0$ indicates that gene action is complementary epistatis, and skewness $<0$ indicates that duplicate epistatic gene action is present. Trait which is controlled by many genes is indicated by kurtosis value of $-3<$ kurtosis $<3$ and the trait which is controlled by little genes, will be $>3$ or $<-3$ in kurtosis value. The distribution of $-3<$ kurtosis $<3$ will form mesocurtic, $>3$ leptocurtic and $<-3$ platicurtic curve.

Estimation of broad-sense and narrow-sense heritability value is counted based on population data of $\mathrm{P}_{1}, \mathrm{P}_{2}, \mathrm{~F}_{1}, \mathrm{~F}_{2}, \mathrm{BC}_{1} \mathrm{P}_{1}$ and $\mathrm{BC}_{1} \mathrm{P}_{2}$ based on J. Warner method. According to El-Hashash [8], this method could display a higher significant in narrow-sense heritability analysis. Broad-sense heritability value estimation use population $\mathrm{P}_{1}, \mathrm{P}_{2}, \mathrm{~F}_{1}$ and $\mathrm{F}_{2}$ :

Where,

$$
h_{b s}^{2}=\frac{\sigma_{g}^{2}}{\sigma_{p}^{2}} x 100 \%
$$

$$
\begin{gathered}
\sigma_{p}^{2}=\sigma_{F 2}^{2} \\
\sigma_{E}^{2}=\frac{\sigma_{P 1}^{2}+\sigma_{P 2}^{2}+\sigma_{F 1}^{2}}{3} \\
\sigma_{g}^{2}=\sigma_{p}^{2}-\sigma_{E}^{2} \\
\sigma_{p}^{2} \quad: \text { phenotypic variance } \\
\sigma_{E}^{2} \quad: \text { environment variance } \\
\sigma_{g}^{2} \quad: \text { genotypic variance }
\end{gathered}
$$


Narrow-sense heritability value estimation use is counted by formulae:

$$
h_{n s}^{2}=\frac{2 \sigma_{F 2}^{2}-\left(\sigma_{B C P 1}^{2}+\sigma_{B C P 2}^{2}\right)}{\sigma_{F 2}^{2}} \times 100 \%
$$

$\begin{array}{ll}\text { Where, } & \\ \sigma_{F 2}^{2} & \text { : Variance of } \mathrm{F}_{2} \text { population (phenotypic varian) } \\ \sigma_{B C P 1}^{2} & : \text { Variance of } \mathrm{BC}_{1} \mathrm{P}_{1} \text { population, backcross of } \mathrm{F}_{1} / \mathrm{P}_{1} \\ \sigma_{B C P 2}^{2} & : \text { Variance of } \mathrm{BC}_{1} \mathrm{P}_{2} \text { population, backcross of } \mathrm{F}_{1} / \mathrm{P}_{2}\end{array}$

While the genetical model was estimated using scaling test and joint scaling test. Scaling test is used for testing the presence of gene interaction, while joint scaling test for estimating the genetical model in a traits inheritance pattern through generation mean of the six population based on Singh and Chaudary method as used by Said [9]. Using six population i.e $\mathrm{P}_{1}, \mathrm{P}_{2}, \mathrm{~F}_{1}, \mathrm{~F}_{2}, \mathrm{BC}_{1} \mathrm{P}_{1}, \mathrm{BC}_{1} \mathrm{P}_{2}$ and its reciprocal population $\mathrm{P}_{1}, \mathrm{P}_{2}, \mathrm{~F}_{1} \mathrm{R}, \mathrm{F}_{2} \mathrm{R}$, $\mathrm{BC}_{1} \mathrm{P}_{1}, \mathrm{BC}_{1} \mathrm{P}_{2}$, the genetical model can be defined. The full model can be divided into two type, i.e set $\mathrm{A}$ define as the model using additive-dominance gene action, and those set $\mathrm{B}$ using dominance-dominance gene action. The formulae of set A (7) and set B (8) as follows:

$$
\begin{aligned}
& Y=0+m+a+d+a a+a d \\
& Y=0+m+a+d+a a+d d
\end{aligned}
$$

All these genetical model was analised by using PBTolls.

\section{Result and discussion}

Mean of all populations studied is presented at Table 2. All population showed large $(>30)$ coefficient of variation $(\mathrm{CV})$ in tertiary panicle branches traits. The $\mathrm{CV}$ value described a variation in a trait was being observed [10]. The value of CV presented the reliability of the experiment through the level of treatments accuracy. The lower CV value, the higher precision rate of an experiment [11]. The value of CV that can be accepted will be vary according to the nature of the traits are being studied. Based on this explanation, it could be estimated that tertiary branches panicle traits showed instability and had a broad variation in nature. This case also supported by a broad range of the lowest and the highest of observed value. The large value of $\mathrm{CV}$ in the trait of tertiary panicle branches has also been reported by Rahayu et al. [12] at $70.07 \%$ in $\mathrm{F}_{2}$ and $34.65 \%$ in $\mathrm{F}_{2} \mathrm{R}$ population which were resulted from crossing of IPB175-F-7-2-1/IPB175-F-31-2-1. 
Table 2. Estimated generation means and standard deviation, variance, $\mathrm{CV}$, and range value of $\mathrm{P}_{1}, \mathrm{P}_{2}, \mathrm{~F}_{1}, \mathrm{~F}_{1} \mathrm{R}, \mathrm{F}_{2}, \mathrm{~F}_{2} \mathrm{R}, \mathrm{BC}_{1} \mathrm{P}_{1}$ and $\mathrm{BC}_{1} \mathrm{P}_{2}$ population for tertiary panicle branches traits in rice

\begin{tabular}{|c|c|c|c|c|c|c|}
\hline Population & $\mathrm{n}$ & Traits & Means \pm SD & Variance & CV (\%) & Range \\
\hline \multirow[t]{3}{*}{$\mathrm{P}_{1}$} & \multirow{3}{*}{115} & NTB & $7.3 \pm 2.99$ & 8.91 & 40.82 & $1.7-16.3$ \\
\hline & & NGT & $18.8 \pm 8.23$ & 67.65 & 43.80 & $3.7-42.3$ \\
\hline & & $\% \mathrm{NGT}$ & $6.9 \pm 2.52$ & 6.33 & 36.29 & $1.7-13.9$ \\
\hline \multirow[t]{3}{*}{$\mathrm{P}_{2}$} & \multirow[t]{3}{*}{84} & NTB & $5.7 \pm 3.18$ & 10.14 & 56.11 & $0.3-12.3$ \\
\hline & & NGT & $13.5 \pm 8.29$ & 68.67 & 61.24 & $0.7-32.7$ \\
\hline & & $\%$ NGT & $4.9 \pm 3.12$ & 9.74 & 64.06 & $0.5-15.7$ \\
\hline \multirow[t]{3}{*}{$\mathrm{F}_{1}$} & \multirow[t]{3}{*}{15} & NTB & $8.5 \pm 4.67$ & 21.82 & 54.89 & $4.0-22.7$ \\
\hline & & NGT & $21.8 \pm 12.40$ & 153.83 & 57.01 & $8.7-58.0$ \\
\hline & & $\%$ NGT & $7.1 \pm 2.95$ & 8.71 & 41.77 & $4.0-14.9$ \\
\hline \multirow[t]{3}{*}{$\mathrm{F}_{1} \mathrm{R}$} & \multirow[t]{3}{*}{15} & NTB & $10.7 \pm 3.93$ & 15.46 & 36.71 & $4.7-18.3$ \\
\hline & & NGT & $26.7 \pm 9.82$ & 96.38 & 36.72 & $10.7-47.0$ \\
\hline & & $\%$ NGT & $8.3 \pm 2.62$ & 6.86 & 31.76 & $4.4-14.1$ \\
\hline \multirow[t]{3}{*}{$\mathrm{F}_{2}$} & \multirow[t]{3}{*}{376} & NTB & $8.4 \pm 5.15$ & 26.54 & 61.04 & $0.0-26.3$ \\
\hline & & NGT & $22.2 \pm 13.10$ & 171.46 & 59.10 & $0.0-72.7$ \\
\hline & & $\% \mathrm{NGT}$ & $6.9 \pm 3.44$ & 11.80 & 50.00 & $0.0-21.1$ \\
\hline \multirow[t]{3}{*}{$\mathrm{F}_{2} \mathrm{R}$} & \multirow[t]{3}{*}{194} & NTB & $9.4 \pm 5.65$ & 31.97 & 59.89 & $0.0-28.8$ \\
\hline & & NGT & $23.9 \pm 15.06$ & 226.69 & 62.98 & $0.0-75.8$ \\
\hline & & $\% \mathrm{NGT}$ & $7.3 \pm 3.72$ & 13.81 & 50.69 & $0.0-18.9$ \\
\hline \multirow[t]{3}{*}{$\mathrm{BC}_{1} \mathrm{P}_{1}$} & \multirow[t]{3}{*}{12} & NTB & $7.7 \pm 2.86$ & 8.17 & 37.83 & $3.7-13.7$ \\
\hline & & NGT & $19.2 \pm 8.20$ & 67.32 & 42.68 & $7.7-37.3$ \\
\hline & & $\%$ NGT & $6.7 \pm 2.63$ & 6.89 & 39.14 & $2.8-10.3$ \\
\hline \multirow[t]{3}{*}{$\mathrm{BC}_{1} \mathrm{P}_{2}$} & \multirow[t]{3}{*}{27} & NTB & $9.4 \pm 4.96$ & 24.56 & 53.03 & $1.0-21.3$ \\
\hline & & NGT & $23.4 \pm 13.32$ & 177.42 & 56.96 & $2.0-53.3$ \\
\hline & & $\%$ NGT & $7.0 \pm 3.59$ & 12.90 & 51.24 & $1.0-15.5$ \\
\hline
\end{tabular}

$P_{1}=$ parent $1, P_{2}=$ parent $2, F_{1}=$ hybrid, $F_{1} R=$ reciprocal hybrid, $F_{2}=F_{1}$ descent; $F_{2} R=F_{1} R$ descent, $\mathrm{BC}_{1} \mathrm{P}_{1}=$ backcrossing of $\mathrm{F}_{1}$ to parent $1, \mathrm{BC}_{1} \mathrm{P}_{2}=$ backcrossing of $\mathrm{F}_{1}$ to parent $2 ; \mathrm{n}=$ plant number observed; $\mathrm{SD}=$ standard deviation; $\mathrm{NTB}=$ number of tertiary branches per panicle, $\mathrm{NGT}=$ number of grains on tertiary branches per panicle, $\% \mathrm{NGT}=$ number of grains on tertiary branches per panicle percentage; $\mathrm{CV}=$ coefficient of variation

The maternal effect in $F_{1}$ and $F_{1} R$ population did not exist according to t-test analysis. There was no difference in both populations. The p-value was $>0.05$ indicated that maternal effect or sitoplasmic inheritance was not presence in the inheritance pattern of tertiary panicle branches. (Table 3). The absence of maternal effect means that the crossing offspring of $\mathrm{P}_{1} / \mathrm{P}_{2}$ will be the same with $\mathrm{P}_{2} / \mathrm{P}_{1}$.

Table 3. Homogeneity of variance of $F_{1}$ and $F_{1} R$ population, maternal effect, and result of t-test of $P_{1}$ vs $P_{2}$ and $F_{2}$ vs $F_{2} R$ for tertiary panicle branches traits in rice

\begin{tabular}{|l|l|l|r|r|r|l|l|}
\hline \multirow{2}{*}{ Traits } & \multicolumn{2}{|c|}{$\begin{array}{c}\text { Homogeneity of } \\
\text { variance }\end{array}$} & \multicolumn{2}{|c|}{ Population } & p-value & \multicolumn{2}{|c|}{ t-test } \\
\cline { 2 - 8 } & $\chi^{2}$ & $\mathrm{p}$-value & $\mathrm{F}_{1}$ & $\mathrm{~F}_{1} \mathrm{R}$ & $\mathrm{F}_{1} \mathrm{VsF}_{1} \mathrm{R}$ & $\mathrm{P}_{1} \mathrm{VSP}_{2}$ & $\mathrm{~F}_{2 \mathrm{VSF}_{2} \mathrm{R}}$ \\
\hline NTB & 0.39 & 0.53 & $8.5 \pm 4.67$ & $10.7 \pm 3.93$ & 0.24 & $3.68^{* *}$ & $-2.06^{*}$ \\
\hline NGT & 0.73 & 0.39 & $21.8 \pm 12.40$ & $26.7 \pm 9.82$ & 0.31 & $4.43^{* *}$ & $-1.38^{\text {ns }}$ \\
\hline \%NGT & 0.19 & 0.66 & $7.1 \pm 2.95$ & $8.3 \pm 2.62$ & 0.35 & $6.84^{* *}$ & $-1.44^{\text {ns }}$ \\
\hline
\end{tabular}


$\mathrm{NTB}=$ number of tertiary branches per panicle, NGT $=$ number of grains on tertiary branches per panicle, $\% \mathrm{NGT}=$ number of grains on tertiary branches per panicle percentage; ${ }^{* *}=$ significant at $\mathrm{p}$ $0.01,{ }^{*}=$ significant at $\mathrm{p} 0.05,{ }^{\mathrm{ns}}=$ non-significant at $\mathrm{p} 0.05$

The tertiary panicle branches showed high value of broad-sense heritability, respectively 0.63 for NTB, 0.60 for NGT and 0.54 for \%NGT (Table 4). While the highvalue of narrow-sense heritability only showed in the NTB trait $(0.55)$, the remains were 0.40 for NGT and 0.21 for \%NGT (Table 4). This criteria followed to Sulistyo's et al. report [13] which divided heritability into three classes, i.e high $(>0.5)$, moderate $(0.2-$ $0.5)$ and low $(<0.2)$. The high heritability in number of tertiary panicle branches trait had also been reported by Rahayu et al. [5] at 0.97 in $\mathrm{F} 2$ population and $0.86 \mathrm{~F}_{2} \mathrm{R}$ population. The high broad-sense and narrow-sense heritability indicated that the traits will be highly response to selection [14].

Table. 4 Shapiro-Wilk normality of $\mathrm{F}_{2}$ and $\mathrm{F}_{2} \mathrm{R}$ population and the value of heritability

\begin{tabular}{|l|c|c|c|c|}
\hline \multirow{2}{*}{ Traits } & \multicolumn{2}{|c|}{ SW value } & \multicolumn{2}{c|}{ Heritability } \\
\cline { 2 - 5 } & $\mathrm{F}_{2}$ & $\mathrm{~F}_{2} \mathrm{R}$ & $\mathrm{h}^{2}{ }_{\text {bs }}$ & $\mathrm{h}^{2}{ }_{\text {ns }}$ \\
\hline NTB & $0.99^{* *}$ & $0.94^{* *}$ & 0.63 & 0.55 \\
\hline NGT & $0.96^{* *}$ & $0.93^{* *}$ & 0.60 & 0.40 \\
\hline \%NGT & $0.98^{* *}$ & $0.97^{* *}$ & 0.54 & 0.21 \\
\hline
\end{tabular}

$\mathrm{NTB}=$ number of tertiary branches per panicle, NGT $=$ number of grains on tertiary branches per panicle, $\% \mathrm{NGT}=$ number of grains on tertiary branches per panicle percentage, $* *=$ significant at $\mathrm{p}<$ $0.05, \mathrm{~h}^{2} \mathrm{bs}=$ broad-sense heritability, $\mathrm{h}^{2}$ ns $=$ narrow-sense heritability

The plant samples observed were 376 for $F_{2}$, and 194 for $F_{2} R$ population to form a continuous distribution. The tertiary panicle branches trait reached maximum segregation in $F_{2}$ and $F_{2} R$ population. The performance of $F_{2}$ segregating population in tertiary panicle branches trait is presented at Fig.1. Fig. 1 revealed that it was true there were maximum segregation on the tertiary panicle branches trait. The parents character of tertiary panicle branches trait and its intermediate character appeared in this generation. This phenomenon was similar to segregation on the trait of secondary panicle branches at $24.1-43.6$ branches per panicle as had been reported by Bacha et al. [15]. Based on Shapiro-Wilk normality test, $\mathrm{F}_{2}$ and $\mathrm{F}_{2} \mathrm{R}$ population showed abnormality distribution in all tertiary panicle branches traits (Table 4). Sihaloho et al. [16] declared that abnormality distribution also shown by skewness value which was not equal to zero. The abnormality of value distribution was caused by the presence of non-additive gene contribution. 


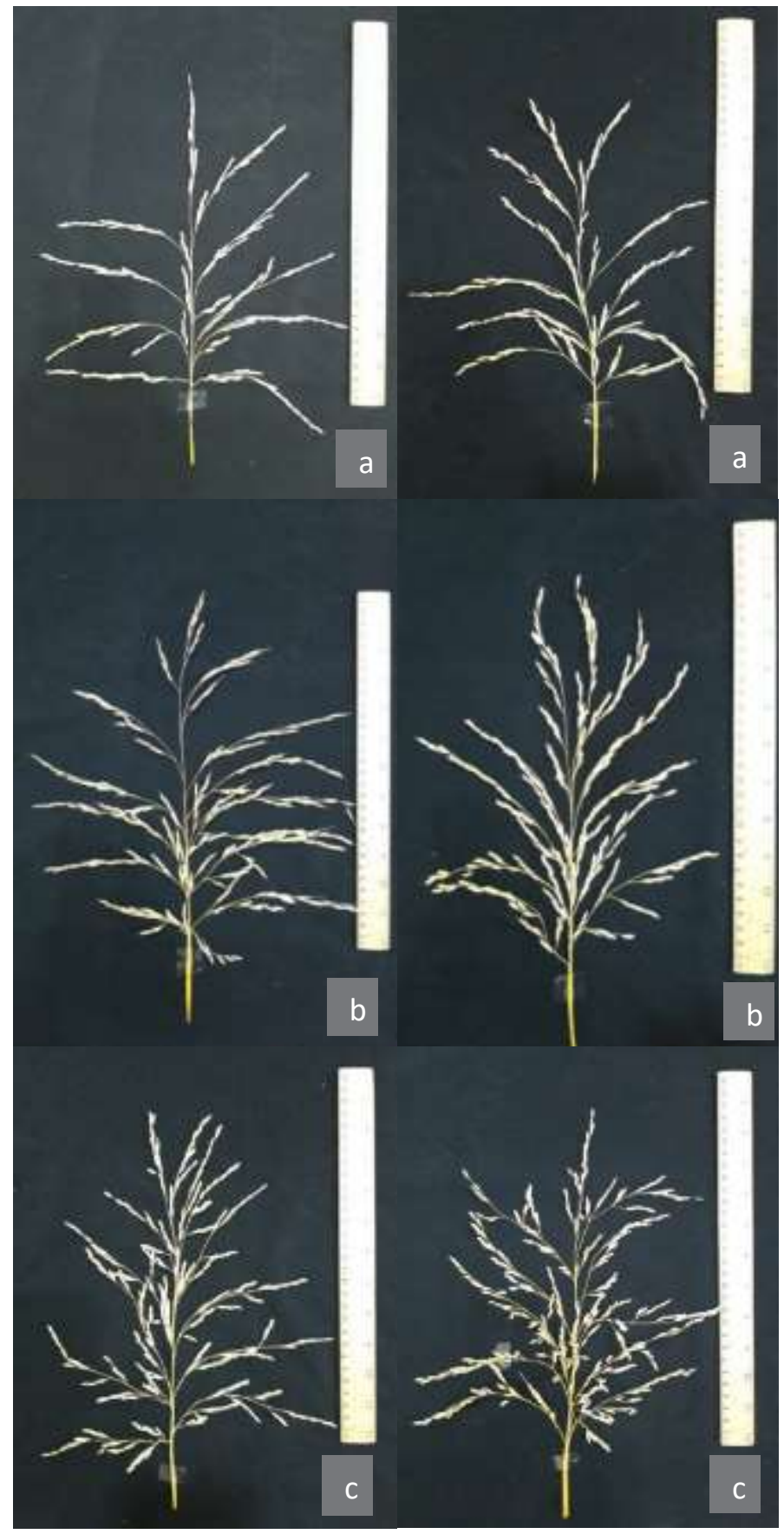

Figure 1. The performance of tertiary panicle branches of $F_{2}$ as a descent of crossing of IPB158-F-5/IPB180-F-12. Number of tertiary panicle branches: (a) little, (b) moderate and (c) many 
Table 5. Estimation type of gene action and number of controlling genes by using skewness dan kurtosis

\begin{tabular}{|c|c|c|c|c|c|c|}
\hline Traits & Skewness & Kurtosis & Zs & $\mathrm{Z}_{\mathrm{K}}$ & Gene action & $\begin{array}{c}\text { Number of } \\
\text { controlling } \\
\text { genes }\end{array}$ \\
\hline \multicolumn{7}{|c|}{$F_{2}$ population } \\
\hline NTB & 0.65 & 0.35 & $5.16^{* *}$ & $1.39^{* *}$ & $\begin{array}{l}\text { aditif, complementary } \\
\text { epistatic }\end{array}$ & many \\
\hline NGT & 0.77 & 0.51 & $6.08^{* *}$ & $2.01^{*}$ & $\begin{array}{l}\text { aditif, complementary } \\
\text { epistatic }\end{array}$ & many \\
\hline$\% \mathrm{NGT}$ & 0.66 & 0.88 & $5.22^{* *}$ & $3.50^{* *}$ & $\begin{array}{l}\text { aditif, complementary } \\
\text { epistatic }\end{array}$ & many \\
\hline \multicolumn{7}{|c|}{$\mathrm{F}_{2} \mathrm{R}$ population } \\
\hline NTB & 0.91 & 0.62 & $5.21^{* *}$ & $1.79^{\operatorname{tn}}$ & $\begin{array}{l}\text { aditif, complementary } \\
\text { epistatic }\end{array}$ & many \\
\hline NGT & 0.98 & 0.77 & $5.57^{* *}$ & $2.20^{*}$ & $\begin{array}{l}\text { aditif, complementary } \\
\text { epistatic }\end{array}$ & many \\
\hline$\% \mathrm{NGT}$ & 0.50 & -0.21 & $2.85^{* *}$ & $-0.62^{\mathrm{tn}}$ & $\begin{array}{l}\text { aditif, complementary } \\
\text { epistatic }\end{array}$ & many \\
\hline
\end{tabular}

NTB $=$ number of tertiary branches per panicle; NGT $=$ number of grains on tertiary branches per panicle; \%NGT = number of grains on tertiary branches per panicle percentage; $Z_{\mathrm{S}}=$ statistical test of $Z$ skewness; $Z_{K}=$ statistical test of $Z$ kurtosis; ${ }^{*}=$ significant at $\mathrm{p} 0.05 ;^{* *}=$ significant at $\mathrm{p} 0.01$

The simplest method to predict gene action was by using skewness and kurtosis. The skewness and kurtosis analysis gave the preliminary explanation that all tertiary panicle branches traits were controlled by additive and complementary-epistatic gene action both in $F_{2}$ and $F_{2} R$ population (Table 5). All the traits were controlled by multiple genes. Similar information also reported by Rahayu et al. [5] that the skewness and kurtosis analysis had resulted the information that tertiary panicle branches traits were controlled by additive and complementary-epistatic gene action with multiple genes. The presence of complementaryepistatic would increase the value of variance, but in contrast the duplicate epistasis would decrease the value of variance, with the central measure was variance when the epistasis was not present. For instance, epistasis and complementary gene action played an important role in kilo-grain weight of rice [17]. In the contrary, Qian et al. [18] confirmed that duplicate epistasis would decrease the value of variance because of reduced of expression.

Table 6. The result of scaling test of crossing IPB158-F-5 $\times$ IPB180-F-12

\begin{tabular}{|l|c|c|c|}
\hline \multirow{2}{*}{ Traits } & \multicolumn{3}{|c|}{ Scaling test } \\
\cline { 2 - 4 } & A & B & C \\
\hline NTB & $-0.71^{\mathrm{tn}} \pm 2.063$ & $4.51^{*} \pm 2.28$ & $3.75^{\mathrm{tn}} \pm 2.67$ \\
\hline NGT & $-2.09^{\mathrm{tn}} \pm 5.77$ & $11.48^{*} \pm 6.11$ & $12.79^{*} \pm 7.05$ \\
\hline$\%$ NGT & $-0.59^{\mathrm{tn}} \pm 1.71$ & $2.08^{\mathrm{tn}} \pm 1.73$ & $1.54^{\mathrm{tn}} \pm 1.73$ \\
\hline
\end{tabular}

NTB $=$ number of tertiary branches per panicle; NGT $=$ number of grains on tertiary branches per panicle; $\% \mathrm{NGT}=$ number of grains on tertiary branches per panicle percentage; $\mathrm{A}=\mathrm{P}_{1}$ scaling test; $\mathrm{B}$ $=\mathrm{P}_{2}$ scaling test $\mathrm{C}=\mathrm{F}_{1}$ scaling test $;{ }^{*}=$ model does not fit at $\alpha 0.05{ }^{\text {tn }}=$ model fit at $\alpha 0.05$

NTB and NGT traits did not fit to additive-dominant model because the significant t-test value presented at one of the three A, B, and C scale based on scaling test. Therefore it was predicted that there was epistatic effect at both traits. While \%NGT trait was not significant in $\mathrm{A}, \mathrm{B}$ and $\mathrm{C}$ scale, so this traits was predicted to fit to additive-dominant model (Table 6). 
Based on this result, only NTB and NGT traits would be continued in the mean generation analysis by using joint scaling test.

Table 7. Estimation of genetical model of rice tertiary panicle branches traits by using joint scaling test based on generation mean of $\mathrm{P}_{1}, \mathrm{P}_{2}, \mathrm{~F}_{1}, \mathrm{~F}_{2}, \mathrm{BC}_{1} \mathrm{P}_{1}, \mathrm{BC}_{1} \mathrm{P}_{2}$ and $\mathrm{P}_{1}, \mathrm{P}_{2}$, $\mathrm{F}_{1} \mathrm{R}, \mathrm{F}_{2} \mathrm{R}, \mathrm{BC}_{1} \mathrm{P}_{1}, \mathrm{BC}_{1} \mathrm{P}_{2}$

\begin{tabular}{|c|c|c|c|c|}
\hline Traits & & Model & $\begin{array}{c}\text { goodness of fit } \\
\text { p-value }\end{array}$ & $\begin{array}{c}\text { regression } \\
\text { p-value }\end{array}$ \\
\hline NTB & \multicolumn{4}{|c|}{ Based on $\mathrm{P}_{1}, \mathrm{P}_{2}, \mathrm{~F}_{1}, \mathrm{~F}_{2}, \mathrm{BC}_{1} \mathrm{P}_{1}$ and $\mathrm{BC}_{1} \mathrm{P}_{2}$ population } \\
\hline \multirow[t]{5}{*}{ Set A } & 1 & $Y=0+m+a+d+a a+a d$ & 0.502 & 0.024 \\
\hline & 2 & $Y=0+m+a+a a+a d$ & 0.755 & 0.000 \\
\hline & 3 & $Y=0+m+a+a a$ & 0.224 & 0.000 \\
\hline & 4 & $\mathrm{Y}=0+\mathrm{m}+\mathrm{aa}$ & 0.003 & 0.000 \\
\hline & 5 & $\mathrm{Y}=0+\mathrm{m}$ & 0.000 & 0.000 \\
\hline \multirow[t]{5}{*}{ Set B } & 1 & $Y=0+m+a+d+a a+d d$ & 0.042 & 0.074 \\
\hline & 2 & $Y=0+m+a+d+d d$ & 0.121 & 0.004 \\
\hline & 3 & $Y=0+m+a+d$ & 0.107 & 0.000 \\
\hline & 4 & $\mathrm{Y}=0+\mathrm{m}+\mathrm{d}$ & 0.002 & 0.000 \\
\hline & 5 & $\mathrm{Y}=0+\mathrm{m}$ & 0.000 & 0.000 \\
\hline NTB & \multicolumn{4}{|c|}{ Based on $\mathrm{P}_{1}, \mathrm{P}_{2}, \mathrm{~F}_{1} \mathrm{R}, \mathrm{F}_{2} \mathrm{R}, \mathrm{BC}_{1} \mathrm{P}_{1}$ and $\mathrm{BC}_{1} \mathrm{P}_{2}$ population } \\
\hline \multirow[t]{3}{*}{ Set A } & 1 & $Y=0+m+a+d+a a+a d$ & 0.422 & 0.032 \\
\hline & 2 & $\mathrm{Y}=0+\mathrm{m}+\mathrm{a}+\mathrm{d}+\mathrm{aa}$ & 0.499 & 0.002 \\
\hline & 3 & $Y=0+m+a+a a$ & 0.502 & 0.000 \\
\hline \multirow[t]{3}{*}{ Set B } & 1 & $Y=0+m+a+d+a a+d d$ & 0.448 & 0.030 \\
\hline & 2 & $Y=0+m+a+a a+d d$ & 0.619 & 0.001 \\
\hline & 3 & $Y=0+m+a+a a$ & 0.502 & 0.000 \\
\hline NGT & \multicolumn{4}{|c|}{ Based on $\mathrm{P}_{1}, \mathrm{P}_{2}, \mathrm{~F}_{1}, \mathrm{~F}_{2}, \mathrm{BC}_{1} \mathrm{P}_{1}$ and $\mathrm{BC}_{1} \mathrm{P}_{2}$ population } \\
\hline \multirow[t]{2}{*}{ Set A } & 1 & $Y=0+m+a+d+a a+a d$ & 0.702 & 0.014 \\
\hline & 2 & $Y=0+m+a+a a+a d$ & 0.929 & 0.000 \\
\hline \multirow[t]{3}{*}{ Set B } & 1 & $Y=0+m+a+d+a a+d d$ & 0.055 & 0.071 \\
\hline & 2 & $\mathrm{Y}=0+\mathrm{m}+\mathrm{a}+\mathrm{aa}+\mathrm{dd}$ & 0.155 & 0.004 \\
\hline & 3 & $Y=0+m+a+a a$ & 0.292 & 0.000 \\
\hline NGT & \multicolumn{4}{|c|}{ Based on $\mathrm{P}_{1}, \mathrm{P}_{2}, \mathrm{~F}_{1} \mathrm{R}, \mathrm{F}_{2} \mathrm{R}, \mathrm{BC}_{1} \mathrm{P}_{1}$ and $\mathrm{BC}_{1} \mathrm{P}_{2}$ population } \\
\hline \multirow[t]{4}{*}{ Set A } & 1 & $Y=0+m+a+d+a a+a d$ & 0.479 & 0.030 \\
\hline & 2 & $Y=0+m+a+a a+a d$ & 0.515 & 0.002 \\
\hline & 3 & $Y=0+m+a+a a$ & 0.160 & 0.000 \\
\hline & 4 & $\mathrm{Y}=0+\mathrm{m}+\mathrm{aa}$ & 0.000 & 0.000 \\
\hline \multirow{4}{*}{ Set B } & 1 & $Y=0+m+a+d+a a+d d$ & 0.055 & 0.081 \\
\hline & 2 & $Y=0+m+a+a a+d d$ & 0.132 & 0.005 \\
\hline & 3 & $Y=0+m+a+a a$ & 0.160 & 0.000 \\
\hline & 4 & $\mathrm{Y}=0+\mathrm{m}+\mathrm{aa}$ & 0.000 & 0.000 \\
\hline
\end{tabular}

$\mathrm{NTB}=$ number of tertiary branches per panicle; JGT $=$ number of grains on tertiary branches per panicle; fit model was in bold type in the appropriate trait of each set.

Advanced analysis of mean generation which was involving more populations $\left(\mathrm{F}_{2}, \mathrm{~F}_{2} \mathrm{R}\right.$, $\mathrm{BC}_{1} \mathrm{P}_{1}$, and $\left.\mathrm{BC}_{1} \mathrm{P}_{2}\right)$ through joint scaling test had given further information. The fit model between observed and expected value was showed by p-value of non-significant goodness of fit ( $p$-value $\geq 0.05$ ) and resulted significant regression model ( $p$-value $<0.05$ ) (Table 7). If there were more than one model showed the fit model, the simplest model was selected.

The genetic estimation of tertiary panicle branches was run based on generation mean analysis of $\mathrm{P}_{1}, \mathrm{P}_{2}, \mathrm{~F}_{1}, \mathrm{~F}_{2}, \mathrm{BC}_{1} \mathrm{P}_{1}$ and $\mathrm{BC}_{1} \mathrm{P}_{2}$ and its reciprocity $\mathrm{P}_{1}, \mathrm{P}_{2}, \mathrm{~F}_{1} \mathrm{R}, \mathrm{F}_{2} \mathrm{R}, \mathrm{BC}_{1} \mathrm{P}_{1}$, and $\mathrm{BC}_{1} \mathrm{P}_{2}$. Set $\mathrm{A}$ was full model of generation mean analysis of $\mathrm{Y}=0+\mathrm{m}+\mathrm{a}+\mathrm{d}+\mathrm{aa}+\mathrm{ad}$, 
while set $\mathrm{B}$ was full model of $\mathrm{Y}=0+\mathrm{m}+\mathrm{a}+\mathrm{d}+\mathrm{aa}+\mathrm{dd}$. The genetic component estimation through generation mean analysis had revealed that NTB and NGT were controlled by additive and additive $\times$ additive interaction gene action. This model appeared three times from two sets (set $\mathrm{A}$ and set $\mathrm{B}$ ) from two population groups $\left(\mathrm{P}_{1}, \mathrm{P}_{2}, \mathrm{~F}_{1}, \mathrm{~F}_{2}\right.$, $\mathrm{BC}_{1} \mathrm{P}_{1}, \mathrm{BC}_{1} \mathrm{P}_{2}$ and $\left.\mathrm{P}_{1}, \mathrm{P}_{2}, \mathrm{~F}_{1} \mathrm{R}, \mathrm{F}_{2} \mathrm{R}, \mathrm{BC}_{1} \mathrm{P}_{1}, \mathrm{BC}_{1} \mathrm{P}_{2}\right)$. The additive $\times$ additive gene action was caused by the presence of a pair of non-allelic gene and showed that parents' alleles was associated or dispersed [19].

From the three analyses of generation mean through skewness, scaling test, and joint scaling test we got the information that tertiary panicle branches traits were inherited by the interaction among locus or known as epistasis. Epistasis is defined as interaction that occur among segregation loci [20]; [21]. Epistasis has effects on a plant phenotype [22]. In the traits of \%NGT, we could see the presence of epistasis effect through skewness analysis, but in-depth analysis through scaling test was proven that \%NGT was controlled by the intra-locus interaction or known as additive-dominant effect. The \%NGT is an indirect trait which was resulted from the comparison of NGT with total grains per panicle. This trait will give the information about tertiary panicle branches contribution to yield. The use of a traits percentage also has been reported by Subbulakshmi et al. [23] in predicting gene action that control between grains and peeled grains percentage. This trait was controlled by dominant and dominant-dominant interaction gene action.

\section{Conclusion}

There was no maternal effects in the inheritance of tertiary panicle branches traits. All the tertiary panicle branches traits showed a large broad-sense heritability, while the narrowsense heritability was moderate, except the number of tertiary panicle branches per panicle was high. The abnormal distribution was showed in $F_{2}$ and $F_{2} R$ population. Based on the kurtosis analysis, it was revealed that tertiary panicle branches traits were controlled by multiple genes. According to skewness analysis, scaling, and joint scaling test, it was obtained the information that the number of tertiary panicle branches and number of grains in the tertiary panicle branches traits were controlled by among locus interaction (epistasis), while the percentage of grains in the tertiary panicle branches was controlled by additive and complementary-additive gene action based on skewness analysis, but by using the indepth analysis through scaling test, it was controlled by additive and dominant gene actions.

\section{References}

1. Y.J. Mo, K.Y. Kim, H.S. Park, J.C. Ko, W.C.Shin, J.K. Nam, B.K. Kim, J.K. Ko, AJCS 6, 436 (2012)

2. P.K. Mohapatra, International Dialogue on Perception and Prospects of Designer Rice (Society for Advancement of Rice Research, Directorate of Rice Research, Hyderabad, 2013)

3. Y. Wang, J. Li, Curr. Opin. Plant Biol 14, 94 (2011)

4. X. Yang, J. Wang, Z. Dai, X. Zhao, X. Miao, Z. Shi, Rice 12, 40 (2019)

5. S. Rahayu, W.B. Suwarno, M. Ghulamahdi, H. Aswidinnoor, SABRAO J BREED GENET 50, 9 (2018)

6. F. Ramadhan, W.B. Suwarno, A. Nindita, H. Aswidinnoor, J. Agron Indonesia 46, 1 (2018)

7. R. Herawati, Masdar, Alnopri, SABRAO J BREED GENET 51, 68 (2019)

8. E.F. El-Hashash, Egypt. J. Plant. Breed 21, 612 (2017) 
9. A.A. Said, Ann. Agric. Sci. 59, 177 (2014)

10. M. Kozak, J. Bocianowski, W. Rybinski, BULG J AGRIC SCI 19, 644 (2013)

11. S. Aerts, G. Haesbroeck, C. Ruwet, J. Multivar. Anal 142, 183 (2015)

12. S. Rahayu, W.B. Suwarno, M. Ghulamahdi, H. Aswidinnoor, J. Agron Indonesia 46, 145 (2018)

13. A. Sulistyo, Purwantoro, K.P. Sari, IOP Conf. Series: Earth and Environmental Science 102, 1 (2018)

14. M.G. Akinwale, G. Gregorio, F. Nwilene, B.O. Akinyele, S.A. Ogunbayo, A.C. Odiyi, Afr. J. Plant Sci 5, 207 (2011)

15. Q.U. Bacha, S.M.A. Shah, Habibullah, I.A. Khalil, A. Muhammad, S.M. Azam, EAR III, 1059 (2015)

16. A.N. Sihaloho, Trikoesoemaningtyas, D. Sopandie, D. Wirnas, J. Agron Indonesia 43, 30 (2015)

17. D. Mao, T. Liu, C Xu, X Li, Y Xing, Euphytica 180, 261 (2011)

18. W. Qian, B. Liao, A.Y. Chang, J. Zhang, Trends Genet 26, 425 (2010)

19. P. Golkar, J. Genet 97, 331 (2018)

20. T.F.C. Mackay, Methods Mol Biol 1253. 47 (2015)

21. L. Crawford, P. Zeng, S. Mukherjee, X. Zhou, PloS Genet 13, 1 (2017)

22. J. Domingo, P. Baeza-Centurion, B. Lehner, Annu. Rev. Genom. Hum. Genet. 20, 17.1 (2019)

23. K. Subbulakshmi, N. Shunmugavalli, A. Muthuswamy, Electron. J. Plant Breed 7, 491 (2016) 